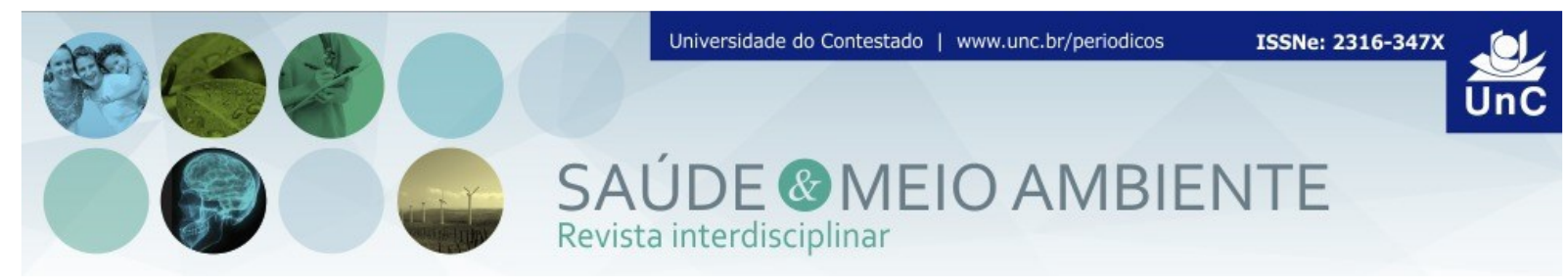

\title{
SELF-MEDICATION IN PATIENTS OF THE BASIC HEALTH UNIT OF A BRAZILIAN CITY
}

\section{AUTOMEDICAÇÃO EM PACIENTES DA UNIDADE DE SAÚDE BÁSICA DE UMA CIDADE BRASILEIRA}

\author{
Dany Geraldo Kramer ${ }^{1}$ \\ Franklin Learcton Bezerra de Oliveira ${ }^{2}$ \\ Geraldo Barroso Cavalcanti Junior ${ }^{3}$
}

\begin{abstract}
The objective of the study was to analyze the prevalence of self-medication among users of Basic Health Units in the city of Monte Alegre - Rio Grande do Norte State, Brazil. A descriptive exploratory study was carried out, through the application of structured questionnaires, with 125 people. It was observed that $83 \%$ of the interviewees practiced self-medication, of these, $34 \%$, they did it monthly. The main justifications for this practice were: difficulty accessing health services $(50 \%)$, financial reasons $(28 \%)$ and lack of time $(22 \%)$. The most used drugs were: analgesic (63\%), anti-inflammatory (13\%) and sedative / hypnotic $(7.0 \%)$. Most $(55 \%)$ claimed to have no or little knowledge about the meaning of self-medication. This demonstrates the need for health education actions in order to educate the population about the risks of this practice, since it can lead to masking of symptoms of diseases, drug interactions and intoxications that compromise the health of the user.
\end{abstract}

Keywords: Health. Drug. Use.

\section{RESUMO}

O objetivo do estudo foi analisar a prevalência de automedicação entre usuários de Unidades Básicas de Saúde da cidade de Monte Alegre - RN / Brasil. Foi realizado um estudo exploratório descritivo, por meio da aplicação de questionários estruturados a 125 usuários. Observou-se que $83 \%$ dos entrevistados praticavam automedicação, destes, 34\%, praticam mensalmente. As principais justificativas para essa prática foram: dificuldade de acesso aos serviços de saúde (50\%), razões

\footnotetext{
${ }^{1}$ Professor Doutor do Programa de Pós-Graduação em Saúde do Família do Nordeste. (RENASF). Universidade Federal do Rio Grande do Norte. Rio Grande do Norte. Brasil. E-mail: dgkcs@yahoo.com.br. OCIRD: https://orcid.org/0000-0001-7655-7444

2Enfermeiro. Discente do Programa de Pós-Graduação em Enfermagem. Universidade Federal do Rio Grande do Norte. Rio Grande do Norte. Brasil. E-mail: franklinlearcton1@gmail.com. OCIRD: https://orcid.org/0000-0002-2927-9653

3 Professor Doutor da Faculdade de Farmácia. Universidade Federal do Rio Grande do Norte. Rio Grande do Norte. Brasil. E-mail: gbcjunior2@hotmail.com OCIRD: https://orcid.org/0000-0001-9227$\underline{4145}$
} 
financeiras $(28 \%)$ e falta de tempo $(22 \%)$. Os medicamentos mais utilizados foram: analgésico $(63 \%)$, anti-inflamatório (13\%), e sedativo / hipnótico $(7,0 \%)$. A maioria $(55 \%)$ afirmou ter pouco ou nenhum conhecimento sobre o significado da automedicação. Os resultados obtidos demonstram a necessidade de ações de educação em saúde para orientar a população sobre os riscos dessa prática, que pode levar ao mascaramento de sintomas de doenças, interações medicamentosas e intoxicações que comprometem a saúde do usuário.

Palavras-chave: Saúde. Medicamento. Uso.

\section{INTRODUCTION}

Self-medication consists of the consumption of a product with the objective of treating or alleviating symptoms and diseases perceived, regardless of the professional prescription. ${ }^{1,2}$ The World Health Organization (WHO) defines selfmedication as an action that involves the use of drugs to treat self-diagnosed disorders or symptoms. May be used industrialized medicines or home remedies, suitable without prescription, reusing old recipes or indication of known people..$^{1,2,3}$

This practice is potentially harmful to individual and collective health, as no medicine is innocuous to the body. The misuse of drugs by the population, such as analgesics, anti-inflammatory drugs, psychotropic drugs and antibiotics, can lead to several consequences such as bacterial resistance, hypersensitivity reactions, dependence, digestive bleeding, liver and kidney damage. In addition, the symptoms of a certain underlying disease may be momentarily masked and may be aggravated. ${ }^{4,5,6,7}$

Prevalence and factors associated with self-medication have been widely studied in developed countries, with prevalence rates between $30 \%$ and $60 \%$ being reported in the literature. ${ }^{8,9}$ Factors contributing to increase of self-medication include economic, political, and cultural aspects, making it a public health problem. Being one of the main, the great availability of products in the pharmaceutical market with dispensing without medical prescription. ${ }^{10,11,12,13}$

Appealing advertisements contrast with timid educational campaigns about the risks of self-medication, inducing the population to acquire the drug, often unnecessarily. ${ }^{9,} 14$ In addition, the difficulty in accessing health services, the high cost of private services, lack of time to remain waiting for care, despair and distress triggered by symptoms or discomfort, lack of regulation and supervision of health sectors, programs ineffective health education, and the influence of close people, are other factors associated with increased self-medication. ${ }^{6,8,8,14}$

In Brazil, according to the Brazilian Association of Pharmaceutical Industries (ABIFARMA), about 80 million people are adept at self-medication. Factors associated with this problem are pointed out in the literature, such as: a large number in the supply of medicines, the dispensation without the prescription, lack of 
information and instruction in the general population and erroneous appointment to the clerk to replace the pharmacist. ${ }^{2,14}$ The patterns of drug use in a society are also determined by the level of education of the people, by the perceptions, values, and beliefs that determine individual attitudes toward finding solutions to health problems. $5,14,16$ These particularities were observed in Brazil, in a study carried out in 600 municipalities with 41,000 people, regarding the use and access to medicines aimed at several health problems, among which, hypertension, depression and diabetes. Difficulties were verified for early diagnosis of the disease and access to medicines, especially in socially disadvantaged regions. ${ }^{15}$

Thus, studies that help governments to know the reasons and forms of selfmedication are relevant, since they can contribute to obtain specific information that allows them to identify strategies and monitor the impact of possible interventions. ${ }^{1,6}$, 14. In this context, the present study aimed to analyze the prevalence of selfmedication among users of basic health units in the municipality of Monte Alegre / RN, Brazil.

\section{METHODS}

\section{PLACE OF STUDY}

This study was carried out in the city of Monte Alegre, located in the mesoregion of Agreste Potiguar, Rio Grande do Norte, Brazil. It presents an approximate population of 25,000 inhabitants, who are attended by eight basic health units and a small hospital.

\section{CHARACTERIZATION OF THE STUDY}

This was an exploratory and descriptive study, using a questionnaire structured with multiple choice alternatives, containing 28 questions about selfmedication habits and socio-demographic data.

To define the samples, inclusion criteria were age (older than eighteen years) and residents of the city of Monte Alegre-RN. The exclusion criteria were never selfmedication or did not wish to participate in the research.

The sample was characterized as non-probabilistic and for convenience, being calculated for this purpose with the software Statistica 10.0, from a universe of people of 20,000 inhabitants, using the confidence level of $5 \%$ and accuracy of $95 \%$. 
A random sample of 125 people was selected (78 female and 47 male). After, 22 were excluded of the research (13 women and nine men) because they answered never to have used medicines without prescription. Thus, 103 people remained in the survey.

\section{DATA TABLING AND ANALYSIS}

The data were tabulated and used to make graphs for analysis and discussions, with the aid of the Microsoft Excel program.

\section{RESULTS AND DISCUSSIONS}

Among the 103 people who remained in the survey, 62.4\% (63 people) were female and $37.6 \%$ (38 people) were male. Of this total, it was observed that $43.68 \%$ (45 people) had incomplete primary education and $70.87 \%$ (73) had family income of up to one minimum wage.

Low levels of income and education are factors that tend to contribute to a public with little access to information, especially with regard to health education topics. Fact, which can influence the inappropriate use of medicines and herbal medicines, which is considered to be a behavior caused by the population's lack of information regarding its risk, since inadequate doses can cause intoxication and mask symptoms of pathologies. ${ }^{9,11,12}$

Of the total, $83 \%$ reported having used or bought over-the-counter medications in the past year. Data similar to the one observed by Laurence et $\mathrm{al}^{16}$, in which they indicate rates of self-medication of more than $60 \%$ among the interviewees, being the majority constituted by women older than 20 years.

Regarding the frequency of the practice of self-medication, the majority, $50 \%$ of the interviewees, responded only once a year. However, $34 \%$ claimed to practice self-medication on a monthly basis (figure 01). 
Figure 1 - Frequency of the practice of self-medication among the interviewees.

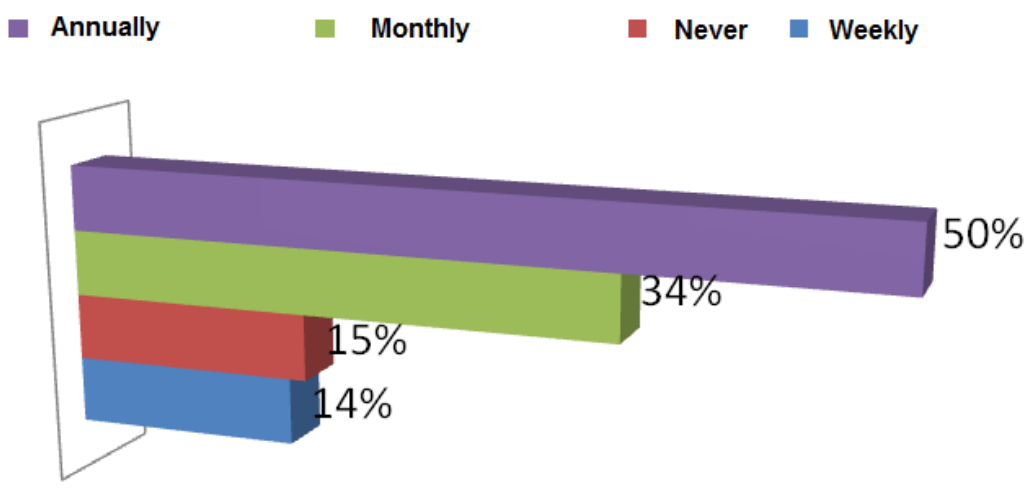

In Brazil, population-based studies on the prevalence and factors associated with self-medication are still incipient, however, it is observed in the literature that this practice is frequent, and at least monthly, mainly with non-steroidal anti-inflammatory drugs. ${ }^{17,} 18$

The main reasons cited by the interviewees, who justify self-medication, were difficulty accessing health services $(50 \%)$, financial reasons $(28 \%)$, lack of time $(22 \%)$ - Figure 2.

Figure 2 - Reasons alleged by interviewees to practice self-medication.

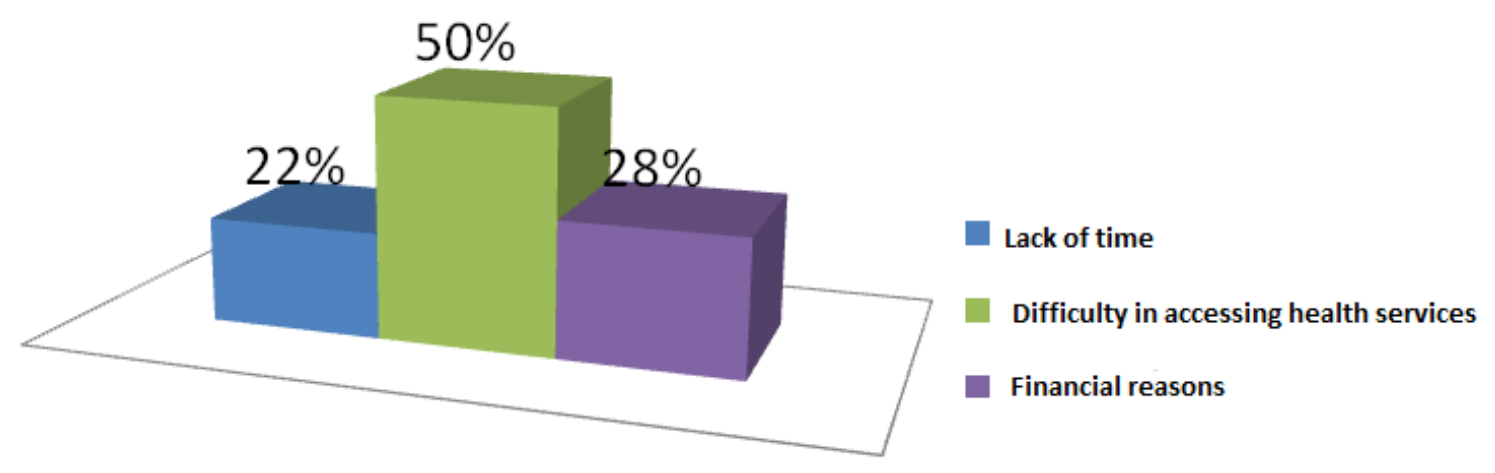

Regarding the most used drugs in self-medication, the interviewees mentioned: analgesic (63\%), anti-inflammatory (13\%), sedative / hypnotic $(7.0 \%)$ others (anti-allergic, anti-helminthic - 17\%). (Figure 03). 
Figura 03 - Medicaments used in self-medication.

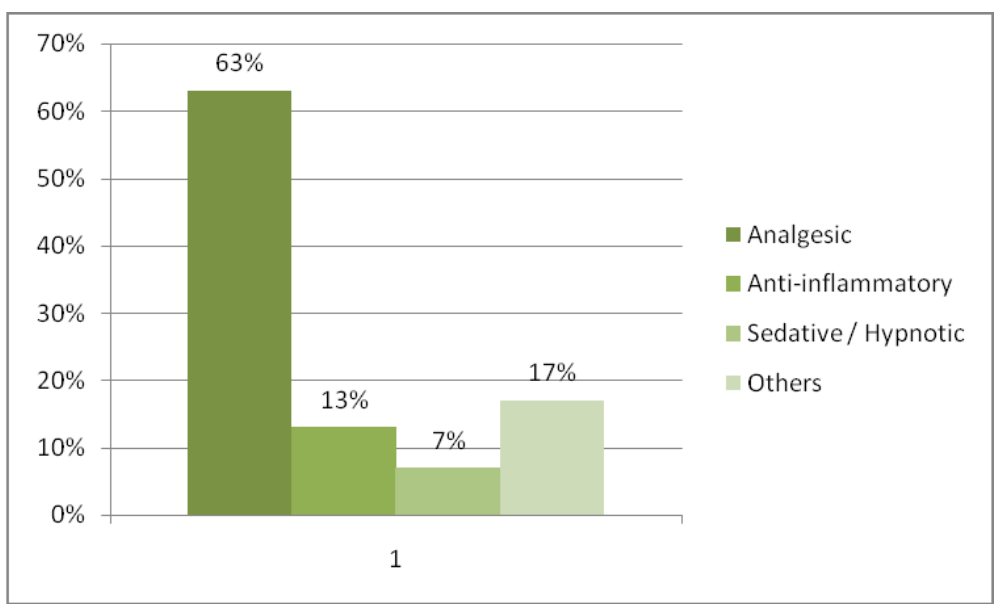

The results found in this study coincide with other studies ${ }^{18,}{ }^{19}$, where prevalence's higher than $50 \%$ of analgesic, antipyretic and non-steroidal antiinflammatory drugs used in self-medication were observed. Controlled-use drugs were obtained from people known to be alleged for temporary relief from an injury. Controlled-use drugs were obtained from people known to be alleged for temporary relief from an injury.

With regard to the main reasons why the interviewee opted for self-medication, they reported feeling or having: pain $(41 \%)$, fever $(29 \%)$ and respiratory disorder $(12 \%)$, being obtained mainly in pharmacies. These data corroborate with other studies, in which headache, respiratory problems, fever and gastrointestinal discomforts are the main reasons for self-medication. ${ }^{18,19}$

When questioned about who indicated the medications, the main response was self-use $(43 \%)$, without influence from relatives, friends or clerk. Followed by the use of old recipes $(31 \%)$.

This topic correlates with other studies, in which self-seeking and the use of old recipes are more prevalent ${ }^{20}$, although in Brazil the clerks play a fundamental role in this practice since they actively act in stimulating the purchase of medicines by patients. $^{20}$

Regarding the level of knowledge of respondents in self-medication, $55 \%$ of them reported lack of knowledge or little knowledge about the meaning of selfmedication (Figure 04). 
Figure 04 - Level of knowledge about self-medication

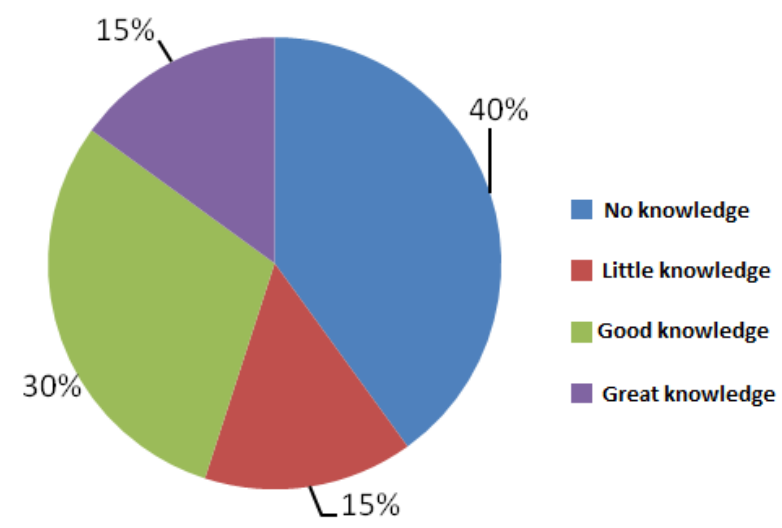

This topic refers to the need to intensify local health education programs so that the population is properly educated about the risks of self-medication.

This is reinforced by the perception of the majority of respondents $(77 \%)$ (figure 05), about the importance of health services to better inform patients about medications (their use, side effects, dosages, conditioning and toxicity).

Figure 05 - Importance of health services to guide the risks of self-medication.

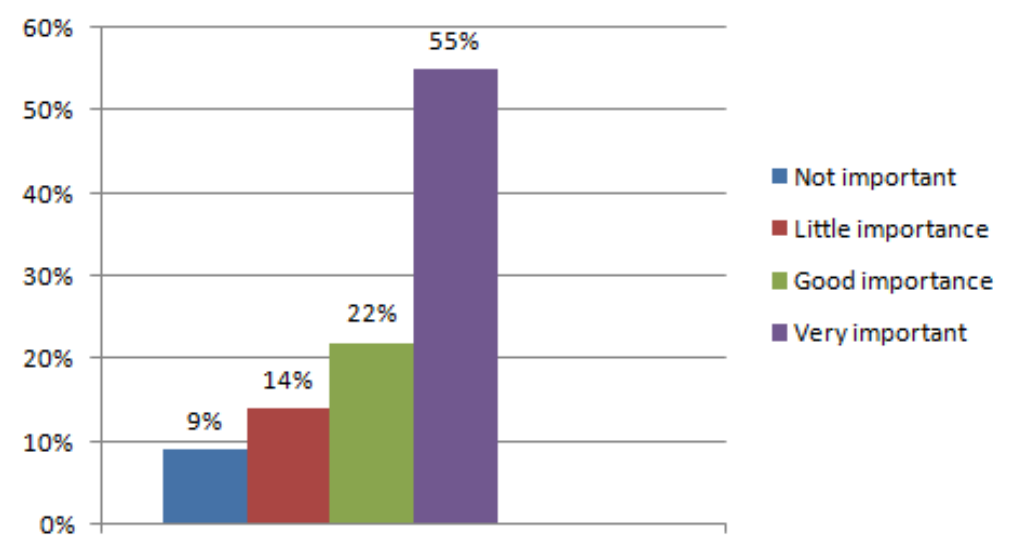

The indiscriminate use of prescription drugs was high in the population evaluated. These drugs may pose a high risk to health, especially with regard to the use of Non-steroidal anti-inflammatory (NSAIDs). These drugs, which are leaders in the ranking of drugs purchased by self-medication, may be associated with numerous serious complications such as: Reye's syndrome and the risk of gastrointestinal bleeding caused by inappropriate use of salicylates; liver damage caused by paracetamol; hemolytic anemia and medullary aplasia due to the 
indiscriminate use of dipyrone. ${ }^{18,19,} 21$

\section{CONCLUSIONS}

It was possible to conclude that self-medication is a common practice in the population of Monte Alegre - RN, with a predominance of analgesics, antiinflammatories and hypnotics. Some of these products are over-the-counter, which favors self-searching or use of old recipes.

This, together with the difficulty of accessing public health services, facilitates this practice and encourages self-medication. Among the risks, this practice for health includes: bacterial resistance, hypersensitivity reactions, dependence, digestive bleeding, liver and kidney damage. In addition, the symptoms of a certain underlying disease may be masked and/or aggravated. Therefore, educational strategies with the local population should be carried out, aiming to reduce this problem.

\section{REFERENCES}

01 Jafari F, Khatony A, Rahamani E. Prevalence of Self-Medication Among the Elderly in Kermanshah-Iran Glob J Health Sci. 2015 Mar; 7(2): 360-365.

02 Domingues PHF, Galvão TF, Andrade KRC. Prevalence of self-medication in the adult population of Brazil: a systematic review. Rev. Saúde Pública 2015; 49:12.

03 Alghanim SA. Self-medication practice among patients in a public health care system Eastern Mediterranean Health Journal. 2011;17(5).

04 Mejia MCB, Restrepo ML, Bernal D.R. (2018) Attitudes, knowledge, and practices regarding self-medication with herbal products and psychotropic drugs among medical students in Medellin, Colombia. Medicina U.P.B; Medellín 2018;37(1): 17-24.

05 Garofalo L, Giuseppe GD, Anelillo IF.. Self-Medication Practices among Parents in Italy. BioMed Research International 2015; 2: 23-34.

06 Lee C, Chang F, Hsu S. Inappropriate self-medication among adolescents and its association with lower medication literacy and substance use. Plos One 2017; 12.

07 Barros GAM, Calonego MAM, Mendes RF, Castro RAN The use of analgesics and risk of self-medication in an urban population sample: cross-sectional study. Brazilian Journal of Anesthesiology (English Edition). 2019 Nov/Dec; 69(6). 
08 Jayita P, Shamshad A, Promiti. Prevalence and pattern of self-medication among undergraduate students in a medical college of Kolkata. International Journal of Community Medicine and Public Health. 2017 Oct; 4(10): 3619-3624.

09 Sankalp Y, Gautam R. Self-medication practice in low income countries. International Journal of Pharmaceutical Chemistry and Analysis 2017; 2: I3.

10 Ahamadi SM, Jamshidi K, Sadeghi K. The Prevalence and Affecting Factors on Self-Medication Among Students of Kermanshah University of Medical Science in 2014. J Clin Diagn Res. 2016 May; 10(5): IC01-IC04.

11 Jambo A, Mengistu G, Sisay M. Self-Medication and Contributing Factors Among Pregnant Women Attending Antenatal Care at Public Hospitals of Harar Town, Ethiopia. Front Pharmacol. 2018; 9: 1063.

12 Azami S, Mohseni M. Prevalence and Cause of Self-Medication in Iran: A Systematic Review and Meta-Analysis Article. Iran J Public Health. 2015 Dec; 44(12): 1580-1593.

13 Levy, M. The Many Faces (and Potential Dangers) of Self-Medication as an Explanatory Concept for Substance Use International Journal for the Advancement of Counselling 2019; 41:15-24.

14 Smirnova M, Owens, JG. Medicalized addiction, self-medication, or nonmedical prescription drug use? How trust figures into incarcerated women's conceptualization of illicit prescription drug use. Social Science \& Medicine 2017 Jun; 183:106-115.

15 Brasil. Ministério da Saúde. Secretaria de Ciência, Tecnologia e Insumos Estratégicos. Componente populacional: resultados. Brasília: Ministério da Saúde; 2016.

16 Laurece RV, Largace L, Ghamwawi S. Drug interactions related to self-medication: a French pharmacovigilance database study Fundamental and Clinical Pharmacology, 2020;2.

17 Pons ES, Kanuth DR, Mengue SS. Predisposing factors to the practice of selfmedication in Brazil: Results from the National Survey on Access, Use and Promotion of Rational Use of Medicines (PNAUM). Plos One, 2017; 2(4).

18 Secoli SR, Marquesini EA, Fabretti SD. Tendency of the practice of selfmedication among Brazilian elderly between 2006 and 2010: SABE study. Revista Brasileira de Epidemiologia, 2018; 21(supl.2).

19 Vernizi MC, Silva LL. The habit of self-medication in adults and elderly: a literature review. Revista Saúde e Desenvolvimento 2016;10(5).

20 Oliveira LL, Moura NPR, Martins-Filho, PRS. Evaluation of self-medication practice in an urban Northeastern population of Brazil Scientia Plena 2016;12: 12-16. 
21 Rodrigues CF. Self-medication with antibiotics in Maputo, Mozambique: practices, rationales and relationships. Palgrave Communications 2020; 6: 6.

Artigo recebido em: 28/04/2020

Artigo aprovado em: 21/08/2020

Artigo publicado em: 28/08/2020 